\title{
Земельный рынок в Центральном Черноземье в 60-90-е годы XIX века
}

\author{
В.А. Тонких ${ }^{1}$, В.В. Громова ${ }^{2}$ \\ ${ }^{1}$ Воронежский государственный университет, \\ Россия, 394018, г. Воронеж, Университетская площадь, 1 \\ ${ }^{2}$ Белгородский государственный национальный исследовательский университет, \\ Россия, 308015, г. Белгород, ул. Победы, 85 \\ E-mail: Gromvv@mail.ru
}

Аннотация. В статье рассматривается проблема развития земельного рынка в пореформенный период на примере Центрально-Черноземных губерний, отличающихся земледельческим укладом. Особое внимание уделяется выявлению общих закономерностей, определению сословного состава участников и степени их вовлеченности в торговые отношения на земельном рынке. За тридцатилетний период с 1863 по 1892 годы проведен анализ сделок по купле-продаже земли, совершенных представителями дворянского, купеческого, крестьянского и мещанского сословий. Определены объемы товарооборота землевладений. Это позволило проследить процесс и степень интеграции указанных сословий в торговлю землей. Из всех губерний Центрально-Черноземного района Курская и Воронежская губернии существенно отличались количеством сделок, совершаемых на их земельных рынках. Курская губерния была на первом месте по количеству сделок купли-продажи земли, Воронежская - на последнем. С помощью статистических данных в указанных губерниях было проанализировано общее количество ежегодно совершаемых сделок, а также средних размеров землевладений, обращающихся на земельных рынках с 1863 по 1892 гг. Это позволило определить динамику развития, спады и подъемы, сходные и отличные черты земельных рынков этих губерний и сопоставить с тенденциями, имеющимися в целом на земельном рынке Центрально-Черноземного района.

Ключевые слова: земельный рынок, продавец, покупатель, сделка, покупка, продажа, десятина, товарооборот.

Для цитирования: Тонких В.А., Громова В.В. 2020. Земельный рынок в Центральном Черноземье в 60-90-е годы XIX века. Via in tempore. История. Политология, 47 (4): 818-825. DOI: $10.18413 / 2687-0967-2020-47-4-818-825$.

\section{The land market of the Central Chernozem region in 60-90-s of the $19^{\text {th }}$ century}

\author{
Vladimir A. Tonkikh ${ }^{1}$, Viktoriya V. Gromova ${ }^{2}$ \\ ${ }^{1}$ Voronezh State University, \\ 1 Universitetskaya Square, Voronezh, 394018, Russia \\ ${ }^{2}$ Belgorod National Research University, \\ 85 Pobeda St., Belgorod, 308015, Russia \\ E-mail: Gromvv@mail.ru
}

Abstract. The article is dedicated to the land market development during the post-reform period, by the 
also to determinate classes of the main of sellers and customers of the land and their level of involvement in trade relation in the land market. Bargains made between 1863 and 1892 by nobles, peasants, merchants and bourgeois were examined. The volume of land trade was determined. As for the Central Chernozem region Kursk and Voronezh regions were the most involved ones in the trade. Kursk region had the most number of deals, Voronezh region had the fewest. The total number of annual transactions and also average sizes of land properties converted in the land market from 1863 to 1892 were examined by means of statistics of the regions mentioned above. All of these points made possible to determine dynamics of development, recessions and booms, similar and different features of land markets of these regions and compare them with current trends in the land market of the Central Chernozem region in whole.

Keywords: land market, seller, customer, transaction, purchase, sale, tithe, trade.

For citation: Tonkih V.A., Gromova V.V. 2020. The land market of the Central Chernozem region in 60-90-s of the 19th century. Via in tempore. History and political science, 47 (4): 818-825 (in Russian). DOI: $10.18413 / 2687-0967-2020-47-4-818-825$.

Основной категорией земель, находившихся в свободном товарообороте на земельном рынке России, были частновладельческие земли. До 1861 года перераспределение земельной собственности происходило в основном внутри дворянского сословия [Ковальченко, 1974, с. 254]. Несмотря на то, что с 1801 года лицам других сословий было разрешено владеть незаселенными землями, земельные переходы были незначительны. С отменой крепостного права постепенно стали сниматься сословные ограничения для свободного перехода земли в собственность других сословий. Вместе с тем основная масса продаваемых земель принадлежала дворянству, а дворянское землевладение в России, как известно, отличалось высокой концентрацией. Крупные размеры продаж сдерживали развитие земельного рынка, так как резко ограничивалось число платежеспособных покупателей [Ковальченко, 1974, с. 257].

В 45 губерниях Европейской России за тридцать лет с 1863 по 1892 гг. товарооборот земельного рынка составил 80727 тыс. десятин, было совершено 565,7 тыс. сделок [Материалы по статистике..., 1901, с. 50-53]. Большая часть земель продавалась крупными участками - на одну сделку приходилось 142,7 дес.

В 10 губерниях Центрально-Черноземного района (Воронежской, Курской, Орловской, Тамбовской, Тульской, Рязанской, Казанской, Пензенской, Рязанской, Саратовской, Симбирской) в 1860 году насчитывалось 30614 дворян-помещиков, в собственности которых находилось 19922 тыс. дес. Из этого количества в первых шести губерниях 23728 дворян имели в собственности 12267 тыс. дес. земли, на каждого владельца дворянского сословия в среднем приходилось по 517 дес. В остальных четырех губерниях насчитывалось 6886 помещиков, в их владении находилось 7655 тыс. дес., средние размеры землевладений составляли 1112 дес. и были в 2,3 раза крупнее, чем в первых шести губерниях [Военно-статистический сборник, 1881, с. 188].

В Центрально-Черноземном районе с 1863 по 1892 годы было совершено 132077 актов по купле-продаже земли, что составляло 23 \% относительно 45 губерний Европейской России. Дворянами, крестьянами, купцами и мещанами района было совершено 115337 сделок по продаже земли и 103346 сделок по ее покупке. Дворяне совершили 56954 сделки по продаже земли и 25455 по покупке, крестьяне (лично) - 45458 и 57 718, купцы - 4983 и 10 298, мещане - 7942 и 9875 соответствующих сделок. От общего количества сделок района это составляло $87 \%$ и 78 \% соответственно. Из них дворяне совершили 43 \% сделок-продаж и $19 \%$ сделок-покупок, крестьяне единоличники - $34 \%$ и $44 \%$, купцы $-4 \%$ и $8 \%$, мещане $-6 \%$ и $7 \%$ соответственно. Если к этому количеству прибавить 4722 сделок-продаж и 14331 сделок-покупок (4 \% и 11 \%), совершенных крестьянскими товариществами, то получится, что на долю крестьян придется 38 \% и $55 \%$ 
соответствующих сделок, а на указанные сословия с учетом крестьянских товариществ 91 \% сделок-продаж и 89 \% сделок-покупок. Доля крестьянских обществ в сделках на земельном рынке была незначительной и составляла 623 сделки-продажи и 1443 сделкипокупки или $0,5 \%$ и $1 \%$ соответственно. Остальными сословиями, а также разносословными союзами и товариществами, было совершено 8,5 \% сделок-продаж и 10 \% сделокпокупок [Материалы по статистике..., 1901, с. 50-53].

За тридцать лет с 1863 по 1892 годы товарооборот земельного рынка района составил $15 \%$ относительно 45 губерний Европейской России или 11789 тыс. десятин. Из этого количества дворянами было продано 9163 тыс. дес., куплено - 5900 тыс. дес. или $78 \%$ и $50 \%$, купцами - 745 тыс. дес. и 2105 тыс. дес. или $6 \%$ и $18 \%$, крестьянами (единолично) - 472 тыс. дес. и 898 тыс. дес. или $4 \%$ и $8 \%$, мещанами - 275 и 382 тыс. дес. или $2 \%$ и $3 \%$ соответственно. Всего на долю указанных сословий пришлось $90 \%$ проданной и $79 \%$ купленной земли, что составляло 10654 тыс. дес. и 9285 тыс. дес. На долю крестьянских сельских товариществ пришлось $1 \%$ проданной и $4 \%$ купленной земли, крестьянских обществ - $1 \%$ и $2 \%$. Доля почетных граждан составляла $3 \%$ и $5 \%$. Доля юридических лиц (без учета крестьянских обществ и товариществ) составляла $2 \%$ и $5 \%$ соответственно, а доля остальных сословий менее одного процента [Материалы по статистике..., 1901, c. 50-53].

Таким образом, основными продавцами и покупателями на земельном рынке района были дворяне, купцы, крестьяне и мещане. Юридические лица (без учета крестьянских обществ и товариществ) увеличили количество купленной и проданной земли только в последние десятилетие указанного тридцатилетнего периода - с 1883 по 1892 годы.

С 1863 по 1892 годы у основных участников земельного рынка района среднее количество проданной и купленной земли, приходящейся на одну сделку, было следующим: у дворян - 162 дес. на 1 сделку-продажу и 232 дес. на 1 сделку-покупку, у купцов 140 дес. и 203 дес., у крестьян - 11 дес. и 16 дес., у мещан - 32 дес. и 38 дес. соответственно [Материалы по статистике..., 1901, с. 50-53].

У всех из указанных сословий средний размер купленного участка был выше проданного, у дворян и купцов - в 1,4 раза, у крестьян - в 1,5 раза. У мещан данное соотношение было менее существенным и составляло 1,18 раза [Материалы по статистике..., 1901, c. 50-53].

С 1863 по 1881 годы у четырех рассматриваемых сословий торговля землей в целом увеличивалась.

В 1863 году дворяне совершили 1976 сделок по продаже земли и 978 сделок по ее покупке. В 1866 году дворяне совершили 1048 сделок по покупке земли - максимальное количество за тридцатилетний период. В 1867-1870 годах дворяне сократили покупку землевладений на $42 \%$ до 687 сделок. Количество продаж дворянских землевладений с 1863 по 1868 годы выросло на 24\%, а с 1869 по 1877 годы - сократилось на $30 \%$. С 1871 года дворянские сделки-покупки начали расти, с 1878 года начали расти сделкипродажи. Этот рост продолжился до 1880-1881 годов. Таким образом, в 60-х - 70-х годах XIX века количество дворянских сделок на земельном рынке района было подвержено резким колебаниям [Материалы по статистике..., 1901, с. 50-53]. В 1863 году крестьяне совершили 198 сделок по продаже земли и 708 сделок по ее покупке. Количество крестьянских сделок по купле-продаже землевладений росло с небольшими отклонениями до 1881 года [Материалы по статистике..., 1901, с. 50-53].

В 60-х годах XIX века большинство сделок по купле-продаже земли совершали дворяне. В 70-х годах XIX века у крестьян сделок стало больше. С 1870 года они стали больше покупать, чем дворяне, а с 1877 года - и продавать [Материалы по статистике..., 1901, c. 50-53].

Купцы и мещане совершали значительно меньше сделок по купле-продаже земли, чем дворяне и крестьяне. С 1863 по 1871 годы купцы совершали от 277 до 345 сделок по 
покупке земли и от 76 до 136 сделок по ее продаже, мещане - от 106 до 152 сделок по продаже и от 183 до 291 сделок по ее покупке. С 1872 по 1881 годы у купцов и мещан количество сделок по купле-продаже земли увеличивалось [Материалы по статистике..., 1901, с. 50-53].

Таким образом, на земельном рынке района крестьяне увеличивали количество сделок с 1863 по 1881 годы. У дворян, купцов и мещан значительный рост количества сделок начался только в 70-е годы XIX века.

В 1880 и 1881 годах купля-продажа землевладений у этих сословий достигла пика. Исключением были мещане, так как пик продаж их землевладений пришелся на 1892 год. В эти годы дворяне совершили соответственно 2514 и 2526 сделок по продаже земли, крестьяне - 2845 и 3359 сделок, купцы - 235 и 252 сделок, мещане - 388 и 381 сделок. Количество сделок по покупке земли было следующим: у дворян - 1039 и 1014 сделок, у крестьян - 3296 и 3792 сделок, у купцов - 439 и 467 сделок, у мещан - 498 и 464 сделок. В 1881 году, по сравнению с 1863 годом, у дворян сделки-продажи выросли в 1,3 раза, а сделки-покупки - всего на $3 \%$, у крестьян - в 17 и 5 раз, у купцов - в 2,8 раза и в 1,5 раза, у мещан - в 2,7 и 1,8 раз соответственно. Таким образом, с 1863 по 1881 гг. из всех вышеперечисленных сословий наибольший рост числа сделок наблюдался у крестьян [Материалы по статистике..., 1901, с. 50-53].

Начиная с 1882 года на земельном рынке начался спад, продолжавшийся до 1886 года. Вместе с тем в 1884 году количество сделок у всех указанных сословий немного выросло, но в 1885 году спад продолжился.

Больше всего спад затронул основных участников земельного рынка - дворян и крестьян. В 1886 году дворяне совершили минимальное количество сделок за период с 1863 по 1892 годы - 1170 сделок по продаже земли и 559 сделок по ее покупке. В этот год крестьяне совершили 1037 и 1300 соответствующих сделок. По сравнению с 1881 годом количество дворянских сделок-продаж сократилось в 2,2 раза, сделок-покупок в 1,8 раз, крестьянских - в 3,2 раза и 2,9 раза соответственно. У купцов и мещан сокращение числа сделок было менее существенным, чем у дворян и крестьян. Количество купеческих по продаже земли сократилось в 1,16 раз, покупке - в 1,9 раза, мещанских в 1,25 и 1,6 раза соответственно [Материалы по статистике..., 1901, с. 50-53].

В 1887-1891 годах на земельном рынке Центрально-Черноземного района вновь наблюдался подъем. По сравнению с 1886 годом, в 1891 году количество дворянских сделок по продаже земли выросло в 1,3 раза и по покупке - в 1,4 раза, крестьянских - в 2,4 и в 2 раза, мещанских - в 1,5 и в 1,4 раза. У купцов количество сделок по продаже земли сократилось на $19 \%$. Количество сделок по покупке земли выросло в 1,2 раза. При этом в 1885-1892 годах купцы совершали меньше сделок по покупке земли, чем в предыдущие 1863-1884 годы (искл. 1864 г.) [Материалы по статистике..., 1901, с. 50-53].

Несмотря на рост в 1887-1891 годах, общее количество сделок по купле-продаже земли не достигло значений 1880-1882 годов. И только мещане совершили больше сделок по продаже земли, чем в 1880-1881 годах. С 1887 по 1892 годы они ежегодно совершали от 406 до 451 сделок по продаже земли. По сравнению с 1863 годом, в 1892 году количество мещанских сделок по продаже земли выросло в 3,2 раза [Материалы по статистике..., 1901, c. 50-53].

Изменения, происходившие на земельном рынке района, можно разделить на три периода в 60-е - 90-е годы XIX века: с 1863 по 1881 годы количество сделок увеличилось, с 1882 по 1886 годы - сокращалось, с 1887 по 1891 годы - рост возобновился. В 1892 году общее количество сделок сократилось на 5 \%, т. е. проявилась тенденция к спаду.

Таким образом, дворяне чаще продавали землю, купцы, крестьяне и мещане - покупали. По количеству сделок и объему купленной и проданной земли первое место, безусловно, принадлежит дворянам. Купцы занимают второе место по общему объему пло- 
щадей всех сделок, так как, несмотря на в разы меньшее число сделок, средние размеры купеческих купленных и проданных участков лишь немного уступали дворянским.

Крестьяне за рассмотренный тридцатилетний период были на первом месте по количеству сделок-покупок земли и на втором месте по ее продаже. Вместе с тем товарооборот крестьянских землевладений и средний размер проданного и купленного участка на рынке был намного меньше купеческого и дворянского. Мещане совершали в 1,6 раза больше сделок по продаже земли, чем купцы. Количество мещанских сделок по покупке земли было немного меньше купеческих. Объем проданной и купленной мещанами земли был в два раза меньше, чем у крестьян, а средние размеры проданных и купленных участков - больше.

Несмотря на разницу в объемах и количестве совершенных сделок в течение рассматриваемого периода, их изменения стали происходить синхронно у всех указанных сословий. Это позволяет сделать вывод о все большем вовлечении данных сословий в торговые отношения на земельном рынке.

На примере Воронежской и Курской губерний можно детально рассмотреть процессы, происходившие на земельном рынке района в течение тридцатилетнего периода с 1863 по 1892 годы.

За тридцатилетний период с 1863 по 1892 годы в Воронежской губернии было совершено 8143 сделки по купле-продаже земли, в Курской губернии в 5,2 раза больше 42570 сделок. От общего количества сделок района это составляло $6 \%$ и $32 \%$ соответственно. Из всех губерний района Курская губерния была на первом месте по количеству сделок купли-продажи земли, Воронежская - на последнем.

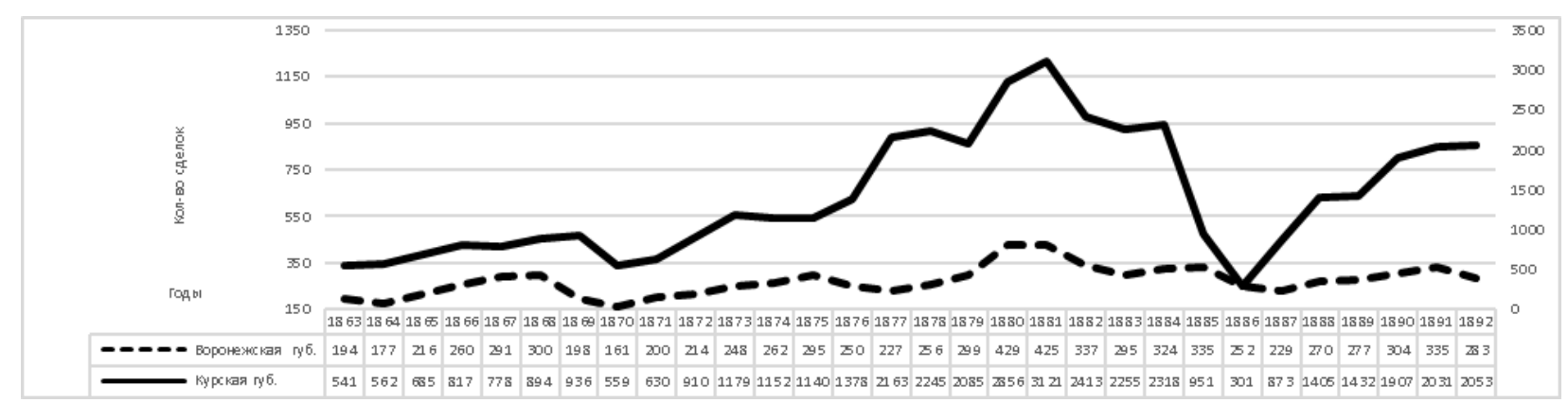

Рис. 1. Количество сделок на земельных рынках Курской и Воронежской губерний с 1863 по 1892 годы [Материалы по статистике..., 1907, табл. IV]

Fig. 1. The quantity of sales on land markets of the Voronezh and Kursk provinces in 1863-1892

В обеих губерниях с 1863 по 1880 годы количество сделок росло с небольшими отклонениями, с 1882 по 1886 годы - сокращалось. С 1871 по 1881 годы в Курской губернии, в отличие от остальных губерний района, наблюдался резкий рост числа сделок купли-продажи земли, затем такое же резкое их падение в 1882-1886 годы. В Воронежской губернии их количество росло более умеренными темпами. В 1881 году в Курской губернии была совершена 3121 сделка купли-продажи земли, в Воронежской - 425 сделок. Это было соответственно в 4 и в 2 раза больше, чем в 1863 году. К 1886 году количество сделок в Курской губернии сократилось в 10 раз до 301 сделки, в Воронежской - в 1,7 раза до 252 сделок. В 1887-1891 годах рост числа сделок вновь возобновился, в 1892 году в Курской губернии он замедлился, а в Воронежской начался спад [Материалы по статистике..., 1907, табл. IV].

Таким образом, несмотря на разницу в количестве совершенных сделок, в обеих губерниях изменение количества сделок в целом происходило циклически и синхронно.

За тридцать лет, с 1863 по 1892 годы, в Воронежской губернии на одну сделку купли-продажи земли в среднем приходилось 135 дес. В 70-х годах XIX века на земельном 
рынке губернии земля продавалась более крупными участками. Так, в 1874 году на одну сделку пришлась 281 десятина. С 1875 года средние размеры участков стали постепенно сокращаться. В 90-е годы XIX века на одну сделку приходилось 78-87 дес. [Материалы по статистике..., 1907, табл. IV].

В Курской губернии земля продавалась самыми мелкими участками относительно других губерний района. С 1863 по 1873 годы на одну сделку приходилось от 27 до 63 дес., с 1872 по 1892 годы - от 15 до 24 дес. [Материалы по статистике..., 1907, табл. IV].

Таким образом, в обеих губерниях в течение рассматриваемого тридцатилетнего периода на одну сделку приходилось все меньше земли.

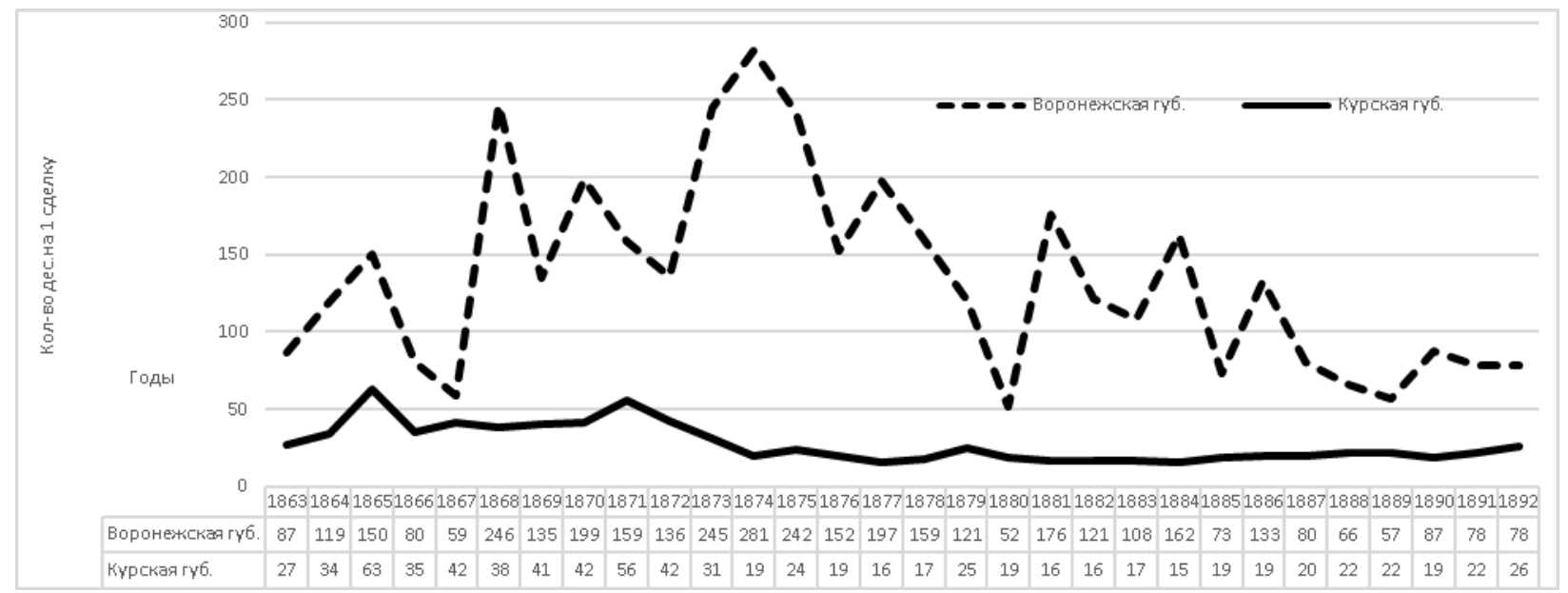

Рис. 2. Количество десятин, приходящиеся на одну сделку купли-продажи на земельных рынках Курской и Воронежской губерний с 1863 по 1892 годы

[Материалы по статистике..., 1907, табл. IV]

Fig. 2. The quantity of tithe on land markets of the Voronezh and Kursk provinces in 1863-1892

\section{Список литературы}

1. Анфимов А.М. 1969. Крупное помещичье хозяйство европейской России (конец XIX начало ХХ в.). АН СССР. Ин-т истории СССР. М., Наука, 394. СПб., 1871.

2. Военно-статистический сборник. Вып. IV. Под ред. генерал-майора Н.Н. Обручева.

3. Ковальченко И.Д., Милов Л.В. 1974. Всероссийский аграрный рынок, XVIII - начало XX в. Опыт количественного анализа. М., Наука, 399.

4. Корелин А.П. 1879. Дворянство в пореформенной России 1861-1904 гг. М., Наука, 304.

5. Князь Васильчиков А. 1876. Землевладение и земледелие в России и других европейских государствах: в 2-х т. СПб., Типография Стасюлевича Т. ІІ. 787.

6. Литвак Б.Г. 1991. Русская деревня в реформе 1861 г. Черноземный центр. 1861-1895 гг. М., Издательство политической литературы, 93.

7. Литуев В.Н. 1997. Земельная собственность как дворянская монополия в капиталистической России. М., Калита, 148.

8. Лященко П.И. 1901. Очерки аграрной эволюции. Спб., б. м., 446.

9. Материалы по статистике движения землевладения в России. Вып. IV: Свод данных о купле-продаже земель в 45 губерниях Европейской России за тридцатилетие с 1863 по 1892 гг. Под ред. А.Е. Рейнбота. СПб., Тип. Киршбаума, 1901.

10. Материалы по статистике движения землевладения в России. Вып. ХІІІ.: Погубернские итоги мобилизации земель и средние земельные цены за 40-летие. 1863-1902 гг. Под ред. А.Е. Рейнбота. СПб., Тип. Киршбаума, 1907.

11. Михалевич В. 1862. Материалы географии и статистики России. Воронежская губерния. Собранные офицерами генерального штаба. СПб., Издательство библиотеки графа Панина, 187.

12. Проскурякова Н.А. 1973. Размещение и структура дворянского землевладения Европейской России в конце XIX - начале XX вв. История СССР. 1: 55-75. 
13. Святловский В.В. 1911. Мобилизация земельной собственности в России (1861-1908 гг.). СПб., Книгоиздательство «Начало», 116.

14. Скребицкий А. 1865. Крестьянское дело в царствование императора Александра II. Бонн-на-Рейне, Т. II. Ч. II. 1624.

15. Статистика землевладения 1905 г. Свод данных по 50 губерниям Европейской России. СПб., ЦСК МВД, 1907.

16. Статистика поземельной собственности и населенных мест Европейской России. Вып. І. СПб., 1880.

17. Статистика землевладения. Воронежская губерния. Вып. V. СПб., ЦСК МВД, 1905.

18. Статистика землевладения. Курская губерния. Вып. XXXVII. СПб., ЦСК МВД, 1906.

19. Фортунатов А.Ф. 1893. Сельскохозяйственная статистика Европейской России. М., Типо-литография т-ва И.Н. Кушнерев, 246.

20. Цифровые данные о поземельной собственности в Европейской России. СПб., 1897.

\section{References}

1. Anfimov A.M. 1969. Krupnoe pomeshhich'e hozjajstvo evropejskoj Rossii (konec XIX nachalo XX v.) [Large-scale estates of European Russia (the late 19th century - early $20^{\text {th }}$ )]. AN SSSR. In-t istorii SSSR. M., Nauka, 394.

2. Voenno-statisticheskij sbornik. Vyp. IV [Military Statistics, ed. 4]. Pod red. general-majora N.N. Obrucheva. SPb., 1871.

3. Koval'chenko I.D., Milov L.V. 1974. Vserossijskij agrarnyj rynok, XVIII - nachalo XX v. Opyt kolichestvennogo analiza [All-Russian agrarian market, 18 - early 20th century. Quantitative analysis attempt]. M., Nauka, 399.

4. Korelin A.P. 1879. Dvorjanstvo v poreformennoj Rossii 1861-1904 gg. [Landed gentry in post-reform Russia (1861-1904)]. M., Nauka, 304.

5. Knjaz' Vasil'chikov A. 1876. Zemlevladenie i zemledelie v Rossii drugih evropejskih gosudarstvah: v 2-h t. [Land tenure and farming in Russia and other European countries: in two volumes]. SPb., Tipografija Stasjulevicha T. II. 787.

6. Litvak B.G. 1991. Russkaja derevnja v reforme 1861 g. Chernozemnyj centr. 1861-1895 gg. [Russian village after the reform of 1861 Central Chernozem region] M., Izdatel'stvo politicheskoj literatury, 93.

7. Lituev V.N. 1997. Zemel'naja sobstvennost' kak dvorjanskaja monopolija v kapitalisticheskoj Rossii [Monopolized land ownership by the nobility in capitalist Russia]. M., Kalita, 148. b. m., 446 .

8. Ljashhenko P.I. 1901. Ocherki agrarnoj jevoljucii [Essays on the agrarian revolution]. Spb.,

9. Materialy po statistike dvizhenija zemlevladenija v Rossii. Vyp. IV: Svod dannyh o kupleprodazhe zemel' v 45 gubernijah Evropejskoj Rossii za tridcatiletie s 1863 po 1892 gg. [Statistics on Russian agricultural progress, ed. 4 . Set of data related to the land mobility in 45 provinces of European Russia during the period from 1863 to 1892]. Pod red. A.E. Rejnbota. SPb., Tip. Kirshbauma, 1901.

10. Materialy po statistike dvizhenija zemlevladenija v Rossii. Vyp. XIII.: Pogubernskie itogi mobilizacii zemel' i srednie zemel'nye ceny za 40-letie. 1863-1902 gg. [Statistics on Russian agricultural progress, ed. 13. Results of land mobility in each province and average land prices during the period from 1863 to 1902]. Pod red. A.E. Rejnbota. SPb., Tip. Kirshbauma, 1907.

11. Mihalevich V. 1862. Materialy geografii i statistiki Rossii. Voronezhskaja gubernija. Sobrannye oficerami general'nogo shtaba [Russian geography and statistics. The province of Voronezh. Data collected by by General Staff officers]. SPb., Izdatel'stvo biblioteki grafa Panina, 187.

12. Proskurjakova N.A. 1973. Razmeshhenie i struktura dvorjanskogo zemlevladenija Evropejskoj Rossii v konce XIX - nachale XX vv. [Placement and formation of noble land ownership in European the late 19th century - early 20th]. Istorija SSSR. 1: 55-75.

13. Svjatlovskij V.V. 1911. Mobilizacija zemel'noj sobstvennosti v Rossii (1861-1908 gg.) [Land mobility in Russia (1861-1908)]. SPb., Knigoizdatel'stvo «Nachalo», 116.

14. Skrebickij A. 1865. Krest'janskoe delo v carstvovanie imperatora Aleksandra II [Peasant cause during the reign of Alexander II. Bonn on the Rhine, vol. II. Part II. 1624]. Bonn-na-Rejne, T. II. Ch. II. 1624. 
15. Statistika zemlevladenija 1905 g. Svod dannyh po 50 gubernijam Evropejskoj Rossii [Land mobility statistics (1905). Set of data on 50 provinces of European Russia]. SPb., CSK MVD, 1907.

16. Statistika pozemel'noj sobstvennosti i naselennyh mest Evropejskoj Rossii. Vyp. I [Statistics of land ownership and localities of European Russia. Ed. 1]. SPb., 1880.

17. Statistika zemlevladenija. Voronezhskaja gubernija [Land ownership statistics. Voronezh Region]. Vyp. V. SPb., CSK MVD, 1905.

18. Statistika zemlevladenija. Kurskaja gubernija [Land ownership statistics. Kursk Region]. Vyp. XXXVII. SPb., CSK MVD, 1906.

19. Fortunatov A.F. 1893. Sel'skohozjajstvennaja statistika Evropejskoj Rossii [Agricultural statistics of European Russia]. M., Tipo-litografija t-va I.N. Kushnerev, 246.

20. Cifrovye dannye o pozemel'noj sobstvennosti v Evropejskoj Rossii [Figures for the land ownership in European Russia]. SPb., 1897.

\section{ИНФОРМАЦИЯ ОБ АВТОРАХ}

Громова Виктория Валентиновна, аспирант кафедры российской истории и документоведения Белгородского государственного национального исследовательского университета, г. Белгород, Россия

Тонких Владимир Алексеевич, доктор исторических наук, профессор кафедры международных отношений и мировой политики Воронежского государственного университета, г. Воронеж, Россия

\section{INFORMATION ABOUT THE AUTHORS}

Viktoriya V. Gromova, postgraduate student of the Department of Russian history and pre-study Belgorod National Research University, Belgorod, Russia

Vladimir A. Tonkih, Doctor of Historical Sciences, Professor of the Department of International Relations and World Politics, Voronezh State University, Voronezh, Russia 